\title{
5C Principles in Profit and Loss Sharing Financing on Baitul Maal Wattamwil as Islamic Micro Finance in Indonesia
}

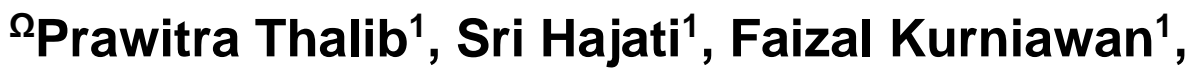 \\ Komari Aldiansyah ${ }^{1}$
}

\author{
1,2,3,4 Faculty of Law, Universitas Airlangga, Indonesia
}

^email correspondence: prawitra@fh.unair.ac.id

\begin{abstract}
Baitul Maal wat Tamwil is a financial institution with a sharia concept that was born as a choice that changes the concept of maal and tamwil in one institution. The concept of maal was born and became part of the lives of Muslim communities in terms of collecting and distributing funds for zakat, infaq and shadaqah) productively. While the Tamwil concept was born for purely business activities to benefit from the middle to micro sectors of society. One of the financing activities carried out by BMT is financing based on profit sharing principles. Profit sharing is done by two types with mudharabah and musyarakah contracts. musyarakah is derived from the word syirkah, also called syarikah, which means a cooperation agreement between two or more parties for certain businesses, each party providing the assistance fund, and will be borne together in accordance with the aid fund, or mutual agreement. The methods used in the writing of this article are normative research using a statute approach and a conceptual approach the result of this research indicates distribution of funds or financing must pay attention to various matters relating to caution both from within and from outside the Islamic Financial Institutions of Islamic Banks and Non-Islamic Banks. Matters issued from internships are in the form of Legal Lending Limit (LLL), financing guidelines, operational aspects. Aside from internal, things that are of caution are also excluded from the external supported by 5C analysis (Character, Condition, Capacity, Capital, Guarantee) and sharia compliance). This analysis must be considered in channeling financing to avoid elements forbidden in Islam.
\end{abstract}

Keywords: 5C Principle; financing; Profit and loss sharing;

Date of Submission: July 23, 2020

Date of Publication: December 28, 2020

DOI: http://dx.doi.org/10.33096/substantivejustice.v3i2.76

\section{INTRODUCTION}

Sharia financial system is the financial system that bridges between the parties who need funds with the parties who have excess funds through financial products and services in accordance with the principles of Sharia. All transactions that occur in the financial 
activities of sharia should be carried out based on the Sharia principal. ${ }^{1}, 2$ Sharia principles are principles based on the teachings of the Qur'an and Sunnah. In the context of Indonesia, the sharia principle is the principle of Islamic law in banking and finance activities based on the fatwa (Islamic legal opinion) issued by Sharia National Board, ${ }^{3}$ the institution that has authority in the determination of fatwa in the field of sharia. To ensure that Sharia finance institutions conduct their business activities based on Islamic principles. In Indonesia, ${ }^{4}$ efforts to regulate the system and financial institutions in accordance with the spirit and principles of Islamic Sharia began to see the results after successfully established the Islamic Bank. ${ }^{5}$ Actually, the intensive efforts of the establishment of Sharia Bank in Indonesia can be traced since 1988, when the government issued the October Policy package (hereinafter called PAKTO) which regulates the deregulation of the banking industry in Indonesia. ${ }^{6}$

Significant developments in Sharia banking in Indonesia occurred in 2008, namely with the enactment of Act No. 21 year 2008 on sharia banking. This Act is in line with the purpose of national development of Indonesia to achieve the creation of fair and prosperous society based on economic democracy, by developing an economic system based on the value of justice, togetherness, equality, and benefits in accordance with the principles of Islamic law. ${ }^{7}$ In the concept of sharia financial institutions, both Sharia commercial Bank (here in after called BUS), Sharia branch office of conventional Bank/Sharia business Unit (hereinafter called UUS), Sharia rural bank (hereinafter called BPRS) and Baitul Maal wat Tamwil (hereinafter called BMT), operating system and sharia concept are not different. What distinguishes BUS, UUS, BPRS and BMT is on its business scale, have activities in raising funds and channeling large amounts of funds, to the society, where the numbers are highly dependent on the risks incurred by the sharia financial institutions. ${ }^{8}$

According to Act No. 20 of 2008 on micro, Small and medium enterprises (hereinafter called MSMES), small businesses are defined as productive economic activities. This business is carried out by individuals or business entities that are not subsidiaries or nonsubsidiaries owned, mastered or part either directly or indirectly from medium enterprises or large enterprises and meet other criteria. Reported from BAPPENAS (Ministry of National Development Planning, Republic of Indonesia) website, in Indonesia, MSME has

${ }^{1}$ Prawitra Thalib, (2013). Syariah Konsep dan Hermeneutika, Surabaya Lutfansyah Mediatama, p.38.

2 Adnan, M. A., \& Ajija, S. R. (2015). The Effectiveness of Baitul Maal wat Tamwil in reducing poverty. Humanomics, 31(2), 160-182. p. 162

${ }^{3}$ Soemitra, A. (2010). Bank \& Lembaga Keuangan Syariah. Jakarta: Kencana. p. 3

${ }^{4}$ Prawitra Thalib, Bagus Oktafian Abrianto, (2019), The Comparative Study of Fiqh Siyasah with the General Principles of Good Government in Indonesia, Arena Hukum, Volume 12, No. 2, Agustus, p. 227

${ }^{5}$ Trisadini Prasastinah,. (2020), Prawitra Thalib, Sharia Principles on Information Technology-Based Financing Services, Yuridika, 35(1), p.158.

${ }^{6}$ Hidayat, R. (2014). Efisiensi Perbankan Syariah: Teori dan Praktik. Bekasi, Gramata Publishing. p. 3

${ }^{7}$ Anshori, A. G. (2009). Perbankan Syari'ah di Indonesia. Yogyakarta: Gadjah Mada University Press. p.7

${ }^{8}$ Muthaher, O. (2012). Akuntansi Perbankan Syariah. Yogyakarta: Graha Ilmu. p. 14-15 
a contribution or big role, including: expansion of employment opportunity and absorption of manpower. Gross domestic product (GDP) formation, the provision of safety nets is especially for low income communities to conduct productive economic activities. Based on data from the Ministry of Cooperatives, small and medium enterprises, the economic census of the Central Statistics agency in 2016 showed the magnitude of small and medium enterprises contribution. MSMES absorbs up to 89.2 percent of the total workforce, providing up to 99 percent of total employment, accounting for 60.34 percent of total national GDP, accounting for 14.17 percent of total exports, accounting for 58.18 percent of the total investment. ${ }^{9}$ Micro Small enterprises has also proved to have the ability to survive in the face of a high crisis, when the economic crisis was in nature by ASEAN countries no exception in Indonesia in 1997-1998, the property business sector experienced a deep downturn, while the micro enterprise sector could still be able to stand. Micro enterprises are also able to keep Indonesia ekonomy not increasingly slumped. ${ }^{10}$

The main problem faced by the MSME sector is the issue of capital, sometimes in gaining a modal from their bank having difficulties. One of the reason is the high credit interest rate and the needs of collateral minded in obtaining credit that they are difficult to fulfill. The provision of credit facilities as the main activity of the banking institutions essentially has the same features since long ago. However, in its current development it leads to variations and patterns that combine technological developments with the accompanying market segments and regulations. ${ }^{11}$ If viewed and in terms of pattern and creditor classification, then one of the banking products in giving credit to the community is through credit micro, small, and medium enterprises (MSMES). ${ }^{12}$

Microfinance institutions (hereinafter called MFIS) are judged to have a major role in supporting government programs to alleviate poverty. MFIS are essentially formed based on the spirit contained in article 27 paragraph (2) and article 3 paragraph (1) and paragraph (4) Constitution of Republic Indonesia 1945. MFIS are institutions that provide financial services for micro entrepreneurs and low-income communities, both formal, semi-formal, and informal. In other words, MFIS are institutions that perform financial services for small and micro entrepreneurs and low-income communities that are not served by formal

${ }^{9}$ Arum Sutrisni, (2019). "Peran UMKM dalam Perekonomian Indonesia", https://www.kompas.com/skola/read/2019/12/20/120000469/peran-umkm-dalam-perekonomianindonesia?page=all\#: :text=Dilansir\%20dari\%20situs\%20Bappenas\%2C\%20di,untuk\%20menjalankan\%20kegi atan\%20ekonomi\%20produktif., (Accessed, June 20, 2020)

${ }^{10}$ Asuransi MAG, "Peran dan Jenis Lembaga Keuangan Mikro di Indonesia", http://www.mag.co.id/lembaga-

keuanganmikro/\#: :text=Jenis\%2DJenis\%20LKM\%20di\%20Indonesia\&text=Contoh\%20dari\%20yang\%20forma 1\%20ini,BPR.\%20Selanjutnya\%20adalah\%20semi\%20formal., (Accessed, Juni 19, 2020)

${ }_{11}$ Salim, A., Rustam, A., Haeruddin, H., Asriati, A., \& Putra, A. H. P. K. (2020). Economic Strategy: Correlation between Macro and Microeconomics on Income Inequality in Indonesia. The Journal of Asian Finance, Economics and Business (JAFEB), 7(8), 681-693.p. 688

${ }^{12}$ Sri Adiningsih, (2019) "Revitalisasi UMKM", http://www.niriah.com, (Accessed, June 19, 2019) 
financial institutions and have been market-oriented for business purposes. MFIS have relatively complete products and fit the needs of low-income communities. ${ }^{13}$

In an effort to encourage community empowerment, especially middle-to-lower income communities MSMES are required comprehensive support from financial institutions. During this time, small and medium enterprises have constrained funding access to formal financial institutions. To overcome these obstacles, in the community has grown and developed many non-bank financial institutions that do business development services activities and community empowerment, either government or community established. ${ }^{14}$ But the MFIS are many who have not been legally licensed and have a business license. In order to provide a strong legal basis for the operationalization of MFIS, on 8 January 2013 has been enacted in Act No. 1 of 2013 on microfinance institutions.

Act No. 1 year 2013 on microfinance institutions defines MFIS as a financial institution specifically established to provide business development services and community empowerment, either through lending or financing in micro-scale efforts to members and communities, the management of deposits, and the provision of business consulting services that are not solely seeking profit. The definition implies that the MFIS is an institution of profit motive which is also social motive, whose activities are more community-development without waiving its role as intermediation institution. As a financial institution that serves as an intermediation institution, MFIS also conduct a lending activity, whose activities in addition to providing loans but also demanded to provide awareness of saving to the public, especially low-income communities. Microfinance itself is a financial sector activity in the form of gathering funds and lending or financing on a micro-scale with a simple procedure to poor and/or low-income people..$^{15}$

There are many kinds of type of MFIS, one of them is BMT which is the MFIS with Islamic principles. BMT is a financial institution with a Islamic concept profit and loss sharing that was born as an option that combines the concept of maa/(property) and tamwil(development) in one institution activity. The concept of maal was born and became part of the Moslem people's life in terms of collecting and channeling funds for zakah, infaq and sadaqah (ZIS) productively. While the concept of tamwil born for pure productive business activities to benefit from the middle and lower community sector (micro). The presence of BMT to absorb the aspirations of the Moslem community in the middle of anxiety of economic activity with the principle of usury or riba, as well as a supporting funding to develop the empowerment activities of small and medium enterprises. The

\footnotetext{
${ }^{13}$ Dewi, N. (2017). Regulasi Keberadaan Baitul Maal Wat Tamwil (BMT) Dalam Sistem Perekonomian di Indonesia. Journal Serambi Hukum, 11(1), p. 96

${ }^{14}$ Kayed, R. N. (2012). The entrepreneurial role of profit-and-loss sharing modes of finance: theory and practice. International Journal of Islamic and Middle Eastern Finance and Management, 5(3), 203-228. p. 222 p. 115

${ }^{15}$ Baskara, I. G. K. (2013). Lembaga Keuangan Mikro di Indonesia. Jurnal Buletin Studi Ekonomi, 189(2),
} 
presence of Sharia microfinance institutions named BMT is perceived to have brought financial benefits to the community, especially the small community that is not bankable and refuse usury or riba, because it is oriented to the societal economy. The presence of BMT on one side of the mission of sharia economics and on the other hand carry the economic tasks of the society by enhancing the micro economy, which is why the development of BMT is very rapidly in the middle development of conventional microfinance institutions. ${ }^{16}$

BMT is a self-contained integrated business Hall that contains maal (property) and tamwil (development) activities to develop productive efforts and investment in improving the quality of economic activities of small and small entrepreneurs with among other things encourage saving activities and support financing of its economic activities. ${ }^{17}$ In addition, BMT can also receive a deposit of zakat, Infak, and charity, and to channel it according to the rules and the mandate. ${ }^{18} \mathrm{BMT}$ consists of two terms, namely baitulmaal and baitul tamwil. baitulmaal further leads to the efforts of collecting and distributing nonprofit funds, such as Zakat, Infaq, and charity. As for the baitul tamwil as a commercial gathering and channeling business. These efforts became an integral part of BMT as a support institution for small community economic activities with the foundation of Islam. ${ }^{19}$ The Institute was established with the intention to facilitate the lower society that is unreachable by Islamic rural bank. Although similar to the Islamic bank, can even be said to be the forerunner of the bank Islam, BMT has its own market share, namely small communities that are not reachable banking services as well as small businesses experiencing "psychological" obstacles when dealing with the bank. ${ }^{20}$

BMT is a microfinance institution that has special characteristics because in its implementation pay attention to the commercial value and social value. In addition, BMT legal entity form that can be in the form of cooperative or PT making regulations that lubricated BMT activities is quite diverse, namely the Act No. 23 year 2011 about the management of Zakat, Act No. 1 year 2013 about microfinance, Act No. 21 year 2011 about the financial Services Authority. In addition to the legislation, there are various regulations that help the implementation of BMT. ${ }^{21}$ The regulations in this concern is the Law No. 25 of 1992 on Cooperatives, Law No. 10 of 1998 on Banking, Law No. 21 of 2008 on Sharia

\footnotetext{
16 Masyitoh, N. D. (2014). Analisis Normatif Undang-Undang Nomor 1 Tahun 2013 Tentang Lembaga Keuangan Mikro (LKM) atas Status Badan Hukum dan Pengawasan Baitul Maal Wat Tamwil (BMT), Jurnal Economica, 5(2), p. 18

${ }^{17}$ Prawitra Thalib,et.,al., (2020), Islamic Law Principles in Islamic Business Activity, International Journal of Innovation Creativity and Change, 13(5), p. 382

${ }^{18}$ Soemitra, A. op.cit., p. 452

19 Komite Nasional Keuangan Syariah, (2019). Rekomendasi Kebijakan: Strategi Pengembangan Keuangan Mikro Syariah di Indonesia, Jakarta: KNKS, p. 21.

${ }_{20}$ Huda, N., \& Heykal, M. (2010). Lembaga Keuangan Islam: Tinjauan Teoritis dan Praktis, Jakarta: Kencana. p. 363

${ }^{21}$ Dewi, N. op.cit., p. 109
} 
Banks, Law No. 40 of 2007 on PT, Decree of the Minister of Cooperatives and SMEs, and Fatwa DSN - MUI. Then detailed in the implementing regulations such as Regulation of the Minister of State for Cooperatives and SMEs No. 16/Per/M.KUKM/IX/2015 on the Implementation of Business Activities to Save Loans and Sharia financing by cooperatives. Regulation of the Minister of Cooperatives and Small and Medium Enterprises of the Republic of Indonesia Number 11/Per/M.KUKM/XII/2017 on The Implementation of Business Activities to Save Sharia Borrowing and Financing by Cooperatives. Regarding compliance with the legislation that depends on the form of the BMT itself. If the form of cooperatives then the legal regime used is an Invitation to Act number 25 year 1992 about the Cooperative (koperasi). Moreover BMT is subject to the legal regime Act No. 1 year 2013 about microfinance institutions. The development of BMT in Indonesia to date has reached the number of networks spread throughout Indonesia and emerged as the propel of real micro-business intermediation. This is evidenced by the number of BMT or the Sharia financial services cooperative that has been developed to Indonesia. Since the first BMT concept in the year 1990 was introduced, there are only a few dozen units, and currently the number of BMT has been more than 5.500.3 BMT growth is so rapidly because it has several proven advantages, namely: 22

1. BMT as a cooperative that is trusted by the wider community to store its funds;

2. As a cooperative for community education members to actively save and plan their finances:

3. BMT as a cooperative that has provided easy and inexpensive financing to members, the majority are micro enterprises;

4. As a sharia-operating business BMT a good living in Islam;

5. BMT encourages people to have a productive attitude and productive action.

BMT is a sharia-based cooperative, which is like other sharia financial institutions. Having business activities to raise funds and disburse funds. Gathering funds on BMT in the form of basic capital (primary deposits and compulsory deposits), the voluntary savings for the results and the voluntary savings of the deposit. Meanwhile, in channeling BMT funds perform credit financing activities under Small business (micro) and small with the akad mudharabah, musyarakah, murabahah, bai and qardul hasan. In addition to channeling and collecting funds, other activities are managing zakat from the innovation to mustahiq.

In providing financing financial institutions have procedures that must be carried out both sharia-based and conventional. Conventional financial institutions such as banks have

${ }^{22}$ Mohamad Anthoni. (2019). "BMT alternatif pemberdayaan ekonomi kerakyatan". http://www.antaranews.com/berita/461826/bmtalternatif-pemberdayaan-ekonomi-kerakyatan, (Accessed, June 22, 2020) 
long and complicated procedures for prospective customers who want to get a loan or financing. Banks are very selective in choosing the credit-kresit they want to implement. This makes msayarakat prefer to other financing institutions. BMT is one option that can be taken. With a simple, fast and easy-to-understand procedure, members feel very helped. There are also BMT institutions that have very simple procedures for applying for a financing, for example someone who will apply for financing is only required to become a member and have savings, or there are also financing decisions based solely on the recommendations of a particular group or person. ${ }^{23}$

Although in providing BMT financing seems very easy, financing can not be given indiscriminately. There is a procedure that must be carried out by a financing agency in providing such a statement. In this context the analysis of $5 \mathrm{c}$ in banking is used. This $5 \mathrm{c}$ analysis is a manifestation of the principle of prudence. In sharia terms analysis $5 \mathrm{c}$ is called the principle of prudent or ikhtiyati. This assessment becomes important as a preventive effort to prevent default by customers. Assessment is carried out so that the financing is received by the right person and can exercise his rights and ness as a BMT customer. In addition to this, considering that BMT uses sharia analysis in carrying out its business activities, the assessment with this $5 \mathrm{c}$ analysis as an effort to implement sharia compliance. In order for BMT as a sharia microfinance institution to continue to run on its rule provide financing in accordance with Sharia. Therefore, this research will discuss how this analysis of $5 \mathrm{C}$ is applied in the disbursing of the results that BMT does with its customers.

The National Committee on Sharia Finance (KNKS) in the Policy Recommendations of Sharia Microfinance Development Strategy in Indonesia mentions the shortcomings of Sharia microfinance institutions in terms of human resources. The understanding of administrators and managers about financial science where not all administrators and managers have a sharia background. Lack of management skill towards financial science (financial institution management techniques). This is a threat to the realization of financing that is in accordance with sharia principles. It also increases the risk of mis-targeting customers, leading to default. Finally, it has an impact on the loss of BMT and threatens the continuity of the BMT.

Departing from the above issues it is important to discuss the process of dissolving the results in this BMT so that the parties associated with this BMT know and understand how to finance procedures. In this paper it will be presented more in what is a $5 \mathrm{C}$ analysis and what legal basis is used. Then it is also explained how the implementation of $5 \mathrm{C}$ analysis relevant to the financing activities of the results share conducted by BMT. Which is hoped

${ }^{23}$ Komite Nasional Keuangan Syariah, (2019). Op.Cit. p. 39. 
to benefit Sharia Microfinance businesses in this context BMT. It is also hoped to benefit people who want to get financing from BMT.

\section{Profit and Loss Sharing in BMT}

This research uses a type of normative legal research. The research, also referred to as literature research, includes research on legal principles, research into legal systematics, research into vertical and horizontal synchronization. In this study, there will be an analysis of various legal principles contained in the process of dissing the BMT. In relation to normative research types, the approach used in this study is the statute approach and conceptual approach. The statute approach is carried out by reviewing all laws and regulations relating to the legal issues currently being addressed. ${ }^{24}$ The concept approach departs from the views and doctrines that develop in the science of law. By studying the views and doctrines of law in law, researchers will find ideas that give birth to legal understandings, concepts of law, and hokum principles about sharia dising perpe to be done by BMT.

In terms of profit and loss sharing is a distribution of several parts of profit to employees of a company. It is further said that it can form an annual cash bonus that is based on profits gained in previous years, or can be in the form of weekly or monthly payments. ${ }^{25}$ In addition, the proportion of profit of each party shall be known at the contracted time and such proportions shall be of profit. The forms of cooperation contracts for the results in sharia financial institutions can generally be done in four akad (Islamic contract), namely musyarakah, mudharabah, muzara'ah and musaqah. However, in its application, the principle used in the profit sharing system, generally using cooperation contracts on the mutanaqisah and mudharabah contract.

In establishing several transaction provisions between BMT and the customer, there have been several matters relating to the mechanism of financing Agreement (contract) and the mechanism of implementation for the outcome. The rule of the matter is theoretically refers to the perspective of the classical fiqh (Islamic jurisprudence) literature, ${ }^{26}$ which is then reactualized by contemporary Sharia practitioners and academics. With regards to financing for the outcome, it is certainly not in relation to society, whether as a customer or non-client. One such association is about how the community actually understands or perceiving the financing for the outcome. The sense of the outline is how the individual understands an object or a target based on observations that have been carried on the knowledge that has been gained from the relevant science.

\footnotetext{
${ }^{24}$ Peter Mahmud Marzuki, (2017). Penelitian Hukum Edisi Revisi, Jakarta: Prenada Media Group. p. 133. ${ }^{25}$ Saeed, A. (2003). Studi Kritis dan Interprestasi Kontemporer tentang Riba dan Bunga. Yogyakarta: Pustaka Pelajar. p. 98 p. 441

${ }^{26}$ Prawitra Thalib, (2018), Distinction of Characteristics Sharia and Fiqh on Islamic Law, Yuridika, 33(3),
} 
In carrying out its business activities every financial institution must apply $5 \mathrm{C}$ (character, capital, capacity, collateral, condition). It is a form of prudence principle. As stipulated in article 2 of the Act No. 10 of 1998 on banking. The purpose of implementing the $5 \mathrm{C}$ principle is to maintain the security, health, stability of the financial system, statutory regulations, and the provisions that apply consistently. This concept of the $5 \mathrm{C}$ does not appear suddenly, but as a thought process through a series of observations on the development of increasingly dynamic and complex financial activities. ${ }^{27}$ Every financial institution must make an initial assessment when the customer submits a financing application with guidance to the $5 \mathrm{C}$ principle. The provision of financing to a customer to be considered, must first be fulfilled the requirements known as the $5 \mathrm{C}$ principle. ${ }^{28} \mathrm{As}$ for the issue of this article is the application of the principle of $5 \mathrm{C}$ by BMT in carrying out its business activities.

\section{Principle of caution (Prudential Principle) in Analysis $5 \mathrm{C}$}

The precautionary principle should always be applied when BMT will distribute its funds to customers. BMT should be able to analyze eligibility in fund channeling. The feasibility study guidelines of the Islamic financial institution disbursement is based on a careful assessment of the factors below. ${ }^{29}$

1. Character Assessment; Assessment of the character of prospective customers/beneficiaries of the facility is mainly based on the relationship that has been established between the Sharia financial institution with the customer/member concerned or information obtained from other trusted parties so that the Sharia financial institutions can conclude that the customers/members of the relevant facilities are honest, in good faith, and do not complicate sharia financial institutions in the future.

2. Capability assessment ; Assessment of the ability of prospective customers/beneficiaries of facilities, especially sharia financial institutions should research about the expertise of customers/members of facilities in the field of business and/or the management capabilities of customers/members. Sharia financial institutions feel confident that the business will be financed by the right people.

${ }^{27}$ Prawitra Thalib, et.,al. (2019), The Function of Deposit Insurances Institution to Create a Solid Banking System for the Sake of Continuity of Infrastructure Development in Indonesia, International Journal of Innovation, Creativity and Change, 5(2), Special Edition, p.394 p. 170

${ }^{28}$ Arthesa, A. \& Handiman, E. (2006). Bank dan Lembaga keuangan Bukan Bank, Jakarta PT Gramedia, Utama, p. 148-149 
3. Capital Assessment; Assessment of the capital owned by prospective customers/beneficiaries, especially the sharia financial institutions must conduct analysis on the overall position of the Quangan, both for past and future estimates for the period to be dating so that it can be known to the capital capability of prospective customers/beneficiary members of facilities in supporting the financing of the project or business prospective customers/members concerned.

4. Collateral Assessment; In conducting assessment of collateral, sharia finance institutions must assess the goods, projects or rights that are financed by the financing facilities concerned and other goods, securities or guarantees of risk added as additional collateral, whether sufficient enough so that if the customer/member of the recipient of the facility will not be able to settle the obligations, such collateral can be used to cover the repayment of financing from the Sharia financial institution

5. Condition Assessment; In conducting assessment of the prospective customer's project/facility beneficiary member, sharia financial institution must primarily conduct analysis on the market situation, both in and outside the country, both for past and future so that it can be known marketing prospects from the result of the project or business of prospective customers. Members who will be financed with financing facilities.

As for one of the prudential principles in Islamic financial institutions both banks and non-banks such as BMT can be described as follows: ${ }^{30}$

1. Customers come to sharia finance institutions by carrying a file of financing application include: (a) financing application letter containing the needs of funds and explanations about everything related to the customer's business. (b) Administrative requirements such as photocopy of the spouse's identity card (KTP), family card, and certificate guarantee.

2. The file is analyzed by the account Officer/marketing part of both the qualitative and quantitative side. As for the juridical side, completeness of licensing and completeness of the company in the field of law analyzed by the financing administration.

3. The financing administration delivers the results of checks to the account officer to be followed up by conducting surveys.

4. The results of the analysis and survey will be reported to the financing Committee to determine whether or not the financing application is approved.

${ }^{30}$ Disarikan dari Tim pengembangan Perbankan Syariah Institut Bankir Indonesia, (2001). Konsep Produk dan Implementasi Operasional Bank Syariah. Jakarta: Djembatan. p. 170-172. 
5. If the application is approved, then the customer will get a letter of approval with the conditions specified by the sharia financial institution, but if rejected, then all the files will be returned to prospective customers.

6. The customer will consider the conditions specified by the Sharia financial institution whether approved or not. If you agree then the customer signs the consent letter.

7. The financing administration will make the financing between customers and banks.

8. After the contract is signed by both sides, the customer submits the application letter of financing realization to disburse the financing funds.

9. During the project, the account officer is required to continue monitoring payment for the proceeds in accordance with the agreed ratio.

10. At the end of the financing contract period, the customer will pay the basic financing to Sharia financial institutions.

\section{Application 5 C Principles in Profit and Loss Sharing in BMT}

The BMT's non-bank financial institutions are not only business oriented, but also social. BMT is also an institution that does not do the centration of wealth on a small majority of capital owners (founders) with an aspiration on the majority of people, but the institutions whose wealth is distributed evenly and fair. ${ }^{31}$ As known, that BMT has two main functions namely funding or gathering and financing or financing. The main principle in this funding management is trust. That means the willingness of people to put their funds on BMT is strongly influenced by the level of community confidence in the BMT itself. Because BMT is principally a trust agency, then each BMT human beings must be able to demonstrate the attitude of the trust. ${ }^{32}$ Whereas in the implementation of BMT financing must have the ability to distribute funds, because this greatly affects the level of performance of the institution. For that allocation of BMT funds should pay attention to the following aspects. ${ }^{33}$

1. Secure, the BMT fund can be guaranteed for its returns,

2. Smoothly, means the turnover can run quickly,

3. Generate, that means allocating funds must be able to provide maximum income,

4. Halal, which means the allocation of BMT funds must be in halal business, both from the review of positive and religious law,

5. Preferred for the development of member economic enterprises.

${ }^{31}$ Muhammad, (2014). Manajemen Dana Bank Syariah. Jakarta: Rajagrafindo Persada. p. 73

${ }_{32}^{32}$ Ridwan, M. (2004) Manajemen Baitul Maal Wa Tamwil (BMT). Yogyakarta: UII Press. p. 149.

${ }_{33}$ Ibid., p. 158-159. 
BMT as a non-bank Islamic financial institution that has permission to do many activities, has a very broad opportunity to earn income (return). However, in the exercise of his activities, to earn income, BMT is always faced with risk. Essentially the risk is inherent on all financial institution activities. The risk in the context of financial institutions is a potential occurrence, both agreement and unpredictable (unanticipated) that negatively impacts income and equity. These risks are unavoidable, but can be managed and controlled. ${ }^{34}$ BMT also requires a set of procedures and methodologies that can be used to identify, measure monitor and control risks arising from business activities. One of the types of risks that BMT will face in general is the risk in financing. This risk occurs as a result of failure by debtor and/or other party to fulfill obligations to BMT. To avoid these aspects of risk, BMT must apply the precautionary principle. The principle of caution is a principle or principle that states that in carrying out functions and business activities must be prudent in order to protect the funds of the community entrusted to it. ${ }^{35}$

In conducting financing, BMT must have confidence in the willingness and ability of prospective customers to settle the entire obligation in time. To obtain the conviction, BMT must conduct a careful assessment of the character, ability, capital, collateral, and the prospect of the business of the prospective customers. This relates to the good faith of the beneficiary's customers to repay the use of the funds channeled by the BMT. Meanwhile, the ability to relate to the state and/or assets of the beneficiary's customers, so as to repay the use of the funds channeled by BMT. To save the property, Islam governs through the law of Muamalat and prohibits actions that can cause harm. Islam appreciates the rights of ownership in private or shared ownership, to the extent that follow the guidance of sharia, then its existence and safety must be protected seriously so as not to happen later, by the individual or collective. ${ }^{36}$

\section{CONCLUSION}

Analysis of $5 \mathrm{C}$ is the mandate of Article 2 of Law No. 10 of 1998 on Banking. In the context of sharia is called "Asas Ikhtiati" or prudent principle. Businesses in the field of Sharia Microfinance, among others, BMT must have clear procedures in providing profit-share financing. The procedure is based on $5 \mathrm{C}$ analysis and takes into account the shariah compliance aspect. Compliance with existing procedures, it is expected to prevent the implementation of the banned financing and can make BMT sustainable. Because sharia microfinancing is one of Islam's approaches to tackling poverty and solving the problem of

\footnotetext{
${ }^{34}$ Karim, A. A. (2006). Bank Islam: Analisis Fiqih dan Keuangan. Jakarta: PT. Raja Grafindo Persada. p. ${ }^{35}$ Usman, R, (2001). op.cit. p.18.

36 Yusuf, M. et al. (2005). Figh dan Ushul Fiqh, Yogyakarta: Pokja Akademik UIN Sunan Kalijaga. p. 88
} 
poverty is the collective obligation (fardhu kifayah) of the Muslim community to take care of the basic needs of the poor. When financing is done in accordance with sharia principles and BMT can be sustainable then it is the embodiment of sharia maqashid namely, protecting religion (hifz al-din), protecting the soul (hifz an-nafs), protecting the mind (hifz al-aql), protecting descendants (hifz al-nasl), and protecting property (hifz al-mal). Basically, the implementation of prudential principle is necessary in financing based on Islamic principles. With the neglect of financial health signs by BMT that conducts activities based on Islamic principles, the impact of loss is far greater than that of a conventional financial institution. The disbursement of funds or financing should observe the various things that are carefully from internal and external financial institutions. The things that come from internal are the provisions of the maximum credit allowance, financing guidelines, operational aspects. Aside from internal, careful things also come from external covering the characteristics of customers using 5C analysis (Character, Condition, Capacity, Capital, Collateral) and Sharia compliance.

\section{REFERENCES}

Adnan, M. A., \& Ajija, S. R. (2015). The effectiveness of Baitul Maal wat Tamwil in reducing poverty. Humanomics, 31(2), $160-182$.

Anshori, A. G. (2018). Perbankan syariah di Indonesia. Yogyakarta. UGM PRESS..

Arthesa, A., \& Handiman, E. (2006). Bank dan lembaga keuangan bukan Bank. Jakarta, PT Indeks Kelompok Gramedia.

Arum Sutrisni, (2019) "Peran UMKM dalam Perekonomian Indonesia", https://www.kompas.com/skola/read/2019/12/20/120000469/peran-umkm-dalamperekonomian-

indonesia?page=all\#: :text=Dilansir\%20dari\%20situs\%20Bappenas\%2C\%20di,unt uk\%20menjalankan\%20kegiatan\%20ekonomi\%20produktif., (Accessed, June 20, 2020).

Asuransi MAG, "Peran dan Jenis Lembaga Keuangan Mikro di Indonesia", http://www.mag.co.id/lembaga-

keuanganmikro/\#: :text=Jenis\%2DJenis\%20LKM\%20di\%20Indonesia\&text=Conto h\%20dari\%20yang\%20formal\%20ini,BPR.\%20Selanjutnya\%20adalah\%20semi\%2 Oformal., (Accessed, Juni 19, 2020).

Baskara, I. G. K. (2013). Lembaga Keuangan Mikro di Indonesia. Jurnal Buletin Studi Ekonomi, 189(2), 114 - 125.

Hidayat, R. (2014). Efisiensi Perbankan Syariah: Teori Dan Praktik. Bekasi: Gramata Publishing.

Huda, N., \& Heykal, M. (2010). Lembaga Keuangan Islam. Jakarta. Kencana. 
Karim, A. A., \& Islam, B. (2006). Analisis Fiqih dan Keuangan, Jakarta: PT. RajaGrafindo Persada.

Kayed, R. N. (2012). The Entrepreneurial Role Of Profit-And-Loss Sharing Modes Of Finance: Theory And Practice. International Journal of Islamic and Middle Eastern Finance and Management, 5(3), 203-228.

Komite Nasional Keuangan Syariah. (2019). Rekomendasi Kebijakan: Strategi Pengembangan Keuangan Mikro Syariah di Indonesia. Jakarta: KNKS.

Mahmud Marzuki, Peter. (2017). Penelitian Hukum Edisi Revisi. Jakarta: Prenada Media Group.

Masyitoh, N. D. (2014). Analisis Normatif Undang-Undang Nomor 1 Tahun 2013 Tentang Lembaga Keuangan Mikro (LKM) atas Status Badan Hukum dan Pengawasan Baitul Maal Wat Tamwil (BMT), Jurnal Economica, 5(2).

Mohamad Anthoni, (2019). "BMT alternatif pemberdayaan ekonomi kerakyatan". http://www.antaranews.com/berita/461826/bmtalternatif-pemberdayaan-ekonomikerakyatan, (Accessed, June 22, 2020).

Muhammad. (2014). Manajemen Dana Bank Syariah. Jakarta: Rajagrafindo Persada.

Muthaher, O. (2012). Akuntansi Perbankan Syariah. Yogyakarta: Graha IImu.

Nourma Dewi. (2017). Regulasi Keberadaan Baitul Maal Wat Tamwil (bmt) dalam Sistem Perekonomian di Indonesia. Serambi Hukum, 11(01), 96-110.

Ridwan, M. (2004). Manajemen Baitul Maal Wa Tamwil (BMT). Yogyakarta: UII Press.

Saeed, A. (2003). Studi Kritis dan Interprestasi Kontemporer tentang Riba dan Bunga. Yogyakarta: Pustaka Pelajar.

Salim, A., Rustam, A., Haeruddin, H., Asriati, A., \& Putra, A. H. P. K. (2020). Economic Strategy: Correlation between Macro and Microeconomics on Income Inequality in Indonesia. The Journal of Asian Finance, Economics and Business (JAFEB), 7(8), 681-693

Soemitra, A. (2010). Bank \& Lembaga Keuangan Syariah. Jakarta: Kencana.

Sri Adiningsih, (2019) "Revitalisasi UMKM", http://www.niriah.com, (Accessed, June 19, 2020).

Syariah, T. P. P. (2001). Konsep Produk dan Implementasi Operasional Bank Syariah. Jakarta: Penerbit Djambatan.

Thalib, P. (2018). Distinction of Characteristics Sharia and Fiqh on Islamic Law. Yuridika, 33(3), 439-452.

Thalib, P., \& Abrianto, B. O. (2019). The Comparative Study Of Fiqh Siyasah With The General Principles Of Good Government In Indonesia. Arena Hukum, 12(2), 215234. 
Usman, R. (2001). Aspek-aspek Hukum Perbankan di Indonesia. Jakarta: PT Gramedia Pustaka Utama.

Yusuf, M. et al. (2005). Figh dan Ushul Fiqh, Pokja Akademik UIN Sunan Kalijaga, Yogyakarta. 